\title{
Soil Test Based Fertilizer Recommendation under Integrated Plant Nutrition System for Vegetable Cowpea [Vigna unguiculata (L) Walp] in Ultisols of Kerala, India
}

\author{
V.I. Beena, P. Dey and R.P. Raji Mol*
}

AICRP on STCR, College of Horticulture, Vellanikkara, 680656, Thrissur, Kerala, India

*Corresponding author

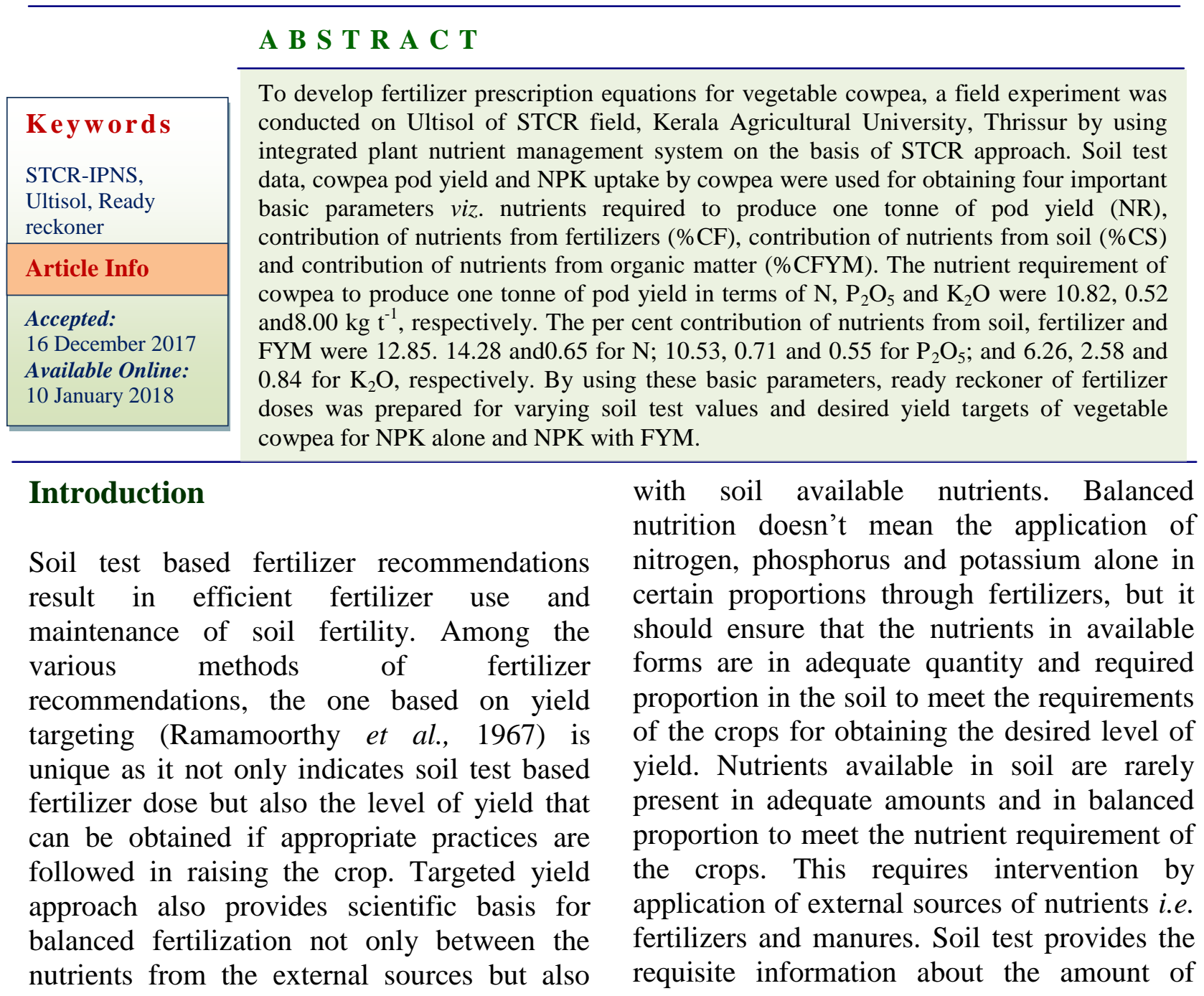


nutrients available in the soil and their imbalances, while fertilizer recommendations aim at correcting the imbalances in nutrients according to crop requirements. The fertilizer recommendations based on qualitative/ semi quantitative approaches or methods do not give expected responses. Therefore, a refined method of fertilizer recommendation for varying soil test values has to be developed.

Cowpea is a typical warm season crop adapted to tropics. Tender pods of cowpea are used as vegetable and dry beans as pulse. Due to its nutritive value and soil nutrient improving properties, it is also used as a fodder, green manure and cover crop. Being a legume crop, cow pea fits well in inter-cropping system. In Kerala, it is grown as a floor crop in coconut gardens, as an inter-crop in tapioca, fringe crop in rice fields and in garden lands. $100 \mathrm{~g}$ of green tender pods contain $4.3 \mathrm{~g}$ protein, 8.0 g carbohydrates, $74 \mathrm{mg}$ phosphorus, $2.5 \mathrm{mg}$ iron, $13.0 \mathrm{mg}$ vitamin C, $0.9 \mathrm{mg}$ minerals, etc.

The existing Package of Practices recommendations for cowpea in Kerala does not take into account the fertility variations in the field and plant uptake from soil and fertilizers, as it does not take into account the fertility variations resulting in imbalanced use of fertilizer nutrients. So far Soil Test Crop Response correlation studies under Integrated Plant Nutrition System (STCR-IPNS) have not been carried out for cowpea in Ultisols of Kerala. Hence the present study was undertaken to develop balanced fertilizer schedule based on STCR to increase the productivity and fertilizer use efficiency in vegetable cowpea.

\section{Materials and Methods}

A field experiment with cowpea (var. Anaswara) was conducted during 2014-2015 at STCR field, College of Horticulture, Vellanikkara in Ultisols. Before starting of experiment the gradient crop, maize (cv. $\mathrm{CO}$ 1) was raised. The experiment was conducted in the same field where the gradient experiment was done. After the harvest of the gradient crop, the soil was analysed from all the three strips and the following data were obtained (Table 1). The soils were in general low to medium in available $\mathrm{N}$, medium to high with respect to available $\mathrm{P}$ and high in available K status.

Each strip was divided into 24 plots/beds of $2.5 \times 3 \mathrm{~m}$ size. The 24 plots in each strip were allotted with 21 treatment combinations of NPK and 3 controls. The FYM at three levels were superimposed in the treatment structure.

The treatment structure was in such a way that each strip received all the treatment combinations. Each strip contained three control plots that had no fertilizers or FYM. The remaining 21 plots of each strip received either FYM or fertilizer or a combination of both. The fertilizer treatment combinations were based on the existing state Package of Practices recommendations i.e. $20 \mathrm{~kg} \mathrm{ha}^{-1}$ of $\mathrm{N}, 30 \mathrm{~kg} \mathrm{ha}^{-1}$ of $\mathrm{N}$ and $10 \mathrm{~kg} \mathrm{ha}^{-1}$ of $\mathrm{K}_{2} \mathrm{O}$, which was also included as one of the treatment combinations (Table 2).

The organic manure as per the treatments was applied in the plots along with full dose of $\mathrm{P}$, half dose of $\mathrm{N}$ and $\mathrm{K}$ as basal. The remaining quantities of $\mathrm{N}$ and $\mathrm{K}$ were applied one month after sowing.

The plants were uprooted carefully after harvest, cleaned and the fresh weight was taken and the yield was recorded and expressed as $\mathrm{t} \mathrm{ha}^{-1}$. The nutrient uptake was computed separately for the fruits and for the biomass (including stems, leaves and roots). The plant samples were analysed separately for the contents of $\mathrm{N}, \mathrm{P}$ and $\mathrm{K}$ after harvest as per standard procedures as described by Piper, 1966. The total uptake of N, P and K were 
computed from the nutrient contents and dry weight of plant parts and expressed as $\mathrm{kg} \mathrm{ha}^{-}$ ${ }^{1}$ as per standard procedures. The fertilizer prescription equations were developed based on the data of soil test values, fruit yield and the nutrient uptake by the vegetable cowpea.

Plot-wise soil test data, fertilizers doses, yield and uptake were used for obtaining NR (nutrient required to produce one tonne of pod yield), \%CS (per cent contribution of nutrients from soil), \%CF (per cent contribution of nutrients from fertilizers) and \%CFYM (per cent contribution of nutrients from FYM), as per method described by Ramamoorthy et al., (1967).

Nutrient requirement in $\mathrm{kg} \mathrm{t}^{-1}$ of grain $(\mathrm{NR})=$ Total uptake of nutrient $\left(\mathrm{kg} \mathrm{ha}^{-1}\right)$ in plot / Grain yield $\left(\mathrm{t} \mathrm{ha}^{-1}\right)$ in plot

Per cent contribution of nutrients from soil $(\% \mathrm{CS})=($ Total uptake of nutrient in control plot $\left(\mathrm{kg} \mathrm{ha}^{-1}\right) /$ (Soil test values of nutrient in control plot $\left.\left(\mathrm{kg} \mathrm{ha}^{-1}\right)\right) \times 100$

Percent contribution of nutrients from fertilizer $(\% \mathrm{CF})=\left\{\left(\right.\right.$ Uptake of $\mathrm{N} / \mathrm{P}_{2} \mathrm{O}_{5} / \mathrm{K}_{2} \mathrm{O}$ by grain+ straw in $\mathrm{kg} \mathrm{ha}^{-1}$ ) - (Soil test value for available $\mathrm{N} / \mathrm{P}_{2} \mathrm{O}_{5} / \mathrm{K}_{2} \mathrm{O}$ in $\mathrm{kg} \mathrm{ha}^{-1} \mathrm{x}$ Percent contribution of $\mathrm{N} / \mathrm{P}_{2} \mathrm{O}_{5} / \mathrm{K}_{2} \mathrm{O}$ from soil/100) $\times 100\} /$ Fertilizer $\mathrm{N} / \mathrm{P}_{2} \mathrm{O}_{5} / \mathrm{K}_{2} \mathrm{O}$ applied in $\mathrm{kg} \mathrm{ha}^{-1}$

These parameters were used to develop equations for soil test based fertilizer recommendations for desired yield targets of vegetable cowpea under NPK alone as well as NPK plus FYM.

\section{Results and Discussion}

\section{Soil available nutrients and pod yield}

The range and mean values of soil available nutrients and pod yield of cowpea in treated and control plots are furnished in table 3. In the NPK treated plots (plots that received $\mathrm{NPK}$ alone or NPK + FYM), $\mathrm{KMnO}_{4}-\mathrm{N}$ increased from 100 to $526 \mathrm{~kg} \mathrm{ha}^{-1}$ with a mean value of $372 \mathrm{~kg} \mathrm{ha}^{-1}$. The Bray-P ranged from $28.94 \mathrm{~kg} \mathrm{ha}^{-1}$ in strip I to $38.07 \mathrm{~kg} \mathrm{ha}^{-1}$ in strip III with a mean value of $33.51 \mathrm{kgha}^{-1}$, while the $\mathrm{NH}_{4} \mathrm{OAc}-\mathrm{K}$ status varied from $502 \mathrm{~kg} \mathrm{ha}^{-1}$ in strip I to $517 \mathrm{~kg} \mathrm{ha}^{-1}$ in strip III with a mean value of $510 \mathrm{~kg} \mathrm{ha}^{-1}$. In the NPK treated plots that received NPK alone or NPK + FYM, the pod yield of cowpea ranged from 2.00 to 5.72 $\mathrm{t} \mathrm{ha}^{-1}$ with a mean value $4.01 \mathrm{t} \mathrm{ha}^{-1}$. In the control plots, the yield ranged from 1.77 to $4.54 \mathrm{tha}^{-1}$ with a mean value of $3.14 \mathrm{t} \mathrm{ha}^{-1}$. In the control plot the $\mathrm{KMnO}_{4}-\mathrm{N}$ ranged from 176 to $298 \mathrm{~kg} \mathrm{ha}^{-1}$ with a mean of $246 \mathrm{~kg} \mathrm{ha}^{-1}$, Bray-P status ranged from 5.0 to $32.03 \mathrm{~kg} \mathrm{ha}^{-1}$ with a mean value of $20.73 \mathrm{~kg} \mathrm{ha}^{-1}$, and the $\mathrm{NH}_{4} \mathrm{OAc}-\mathrm{K}$ status varied from 376 to $653 \mathrm{~kg}$ $\mathrm{ha}^{-1}$ with a mean value of $500 \mathrm{~kg} \mathrm{ha}^{-1}$.

These soils are medium in available $\mathrm{N}$ and medium to high in available $\mathrm{P}$ and high in available $\mathrm{K}$. The above data clearly indicate the existence of operational range of soil test values for available $\mathrm{N}, \mathrm{P}$ and $\mathrm{K}$ status and yield of treated and control plots, which is a prerequisite for calculating the basic parameters and fertilizer prescription equations for calibrating the fertilizer doses for specific yield targets. The results were similar to the findings of Sellamuthu et al., (2015). Almost similar results were found by Bera et al., (2006) and Dwivedi et al., (2009) for on-farm evaluation of soil test based site specific nutrient management in pearl milletbased cropping systems on alluvial soils.

\section{Basic parameters}

The basic data viz., nutrient requirement for producing one tone pod yield of cowpea, percent contribution of nutrients from soil (CS), fertilizer (CF) and FYM (CFYM) have been calculated and furnished in table 4 . 
These basic parameters were used for developing the fertilizer prescription equations under NPK alone and IPNS. The nutrient requirement of cowpea to produce one tonne of pod yield is $10.82 \mathrm{~N} \mathrm{~kg}, 0.52 \mathrm{~kg} \mathrm{P}_{2} \mathrm{O}_{5}$ and 8.00 $\mathrm{K}_{2} \mathrm{O}$, respectively. The percent contribution of nutrients from soil and fertilizers were found to be 12.85 and 14.28 for $\mathrm{N}, 10.53$ and 0.71 for $\mathrm{P}_{2} \mathrm{O}_{5}$ and 6.26 and 2.58 for $\mathrm{K}_{2} \mathrm{O}$. Similarly the percent contribution of $\mathrm{N}, \mathrm{P}_{2} \mathrm{O}_{5}$ and $\mathrm{K}_{2} \mathrm{O}$ from FYM were $0.65,0.55$ and 0.84 , respectively.

Table.1 Gradient crop: Complex experiment

\begin{tabular}{|l|l|l|l|l|}
\hline S1. No. & Strips & $\begin{array}{l}\text { A vailable } \mathbf{N} \\
\left(\mathrm{kg} \mathrm{ha}^{-1}\right)\end{array}$ & $\begin{array}{l}\text { A vailable P } \\
\left(\mathrm{kg} \mathrm{ha}^{-1}\right)\end{array}$ & $\begin{array}{l}\text { A vailable K } \\
\left(\mathrm{kg} \mathrm{ha}^{-1}\right)\end{array}$ \\
\hline 1 & S0 & 245.80 & 20.73 & 500.35 \\
\hline 2 & S1 & 339.75 & 28.94 & 501.87 \\
\hline 3 & S2 & 404.09 & 38.07 & 517.25 \\
\hline
\end{tabular}

Table. 2 Treatment structure of complex experiment

\begin{tabular}{|l|l|l|l|l|}
\hline \multirow{2}{*}{ Nutrient Levels } & \multicolumn{3}{|l|}{ Fertilizer doses $\left(\mathrm{kg} \mathrm{ha}^{-1}\right)$} & FYM $(\mathrm{t} \mathrm{ha}$ \\
& N & P & K & \\
\hline $\mathbf{0}$ & 0 & 0 & 0 & 0 \\
\hline $\mathbf{1}$ & 15 & 25 & 5 & 10 \\
\hline $\mathbf{2}$ & 20 & 30 & 10 & 20 \\
\hline $\mathbf{3}$ & 30 & 40 & 20 & -- \\
\hline
\end{tabular}

Table.3 Available nutrients in soil and yield of vegetable cowpea

\begin{tabular}{|c|c|c|c|c|c|c|}
\hline \multirow[t]{2}{*}{ Parameters } & \multicolumn{3}{|c|}{ NPK treated plot } & \multicolumn{3}{|c|}{ Control plot } \\
\hline & Range & Mean & SEm & Range & Mean & SEm \\
\hline $\begin{array}{l}\mathrm{KMnO}_{4}-\mathrm{N} \\
\left(\mathrm{kg} \mathrm{ha}^{-1}\right)\end{array}$ & $100-526$ & 372 & \pm 17.44 & $176-298$ & 246 & \pm 5.31 \\
\hline $\begin{array}{l}\overline{\text { Bray-P }} \\
\left(\mathrm{kg} \mathrm{ha}^{-1}\right)\end{array}$ & $\begin{array}{l}5.00- \\
79.59\end{array}$ & 33.51 & \pm 4.77 & $\begin{array}{l}5.00- \\
32.03\end{array}$ & 20.73 & \pm 1.83 \\
\hline $\begin{array}{l}\mathrm{NH}_{4} \mathrm{OAc}-\mathrm{K} \\
\left(\mathrm{kg} \mathrm{ha}^{-1}\right)\end{array}$ & $255-691$ & 510 & \pm 21.89 & $376-653$ & 500 & \pm 12.70 \\
\hline $\begin{array}{l}\text { Yield } \\
\left(\mathbf{t ~ h a}^{-1}\right)\end{array}$ & $2.00-5.72$ & 4.01 & \pm 0.177 & $1.77-4.54$ & 3.14 & \pm 0.156 \\
\hline
\end{tabular}

Table.4 Basic data of vegetable cowpea experiment

\begin{tabular}{|l|l|l|l|l|}
\hline Nutrient & NR $\left(\mathrm{kg} \mathrm{t}^{-1}\right)$ & CS $(\%)$ & CF $(\%)$ & COM (\%) \\
\hline F N & 10.82 & 12.85 & 14.28 & 0.65 \\
\hline $\mathrm{F} \mathrm{P}_{2} \mathrm{O}_{5}$ & 0.52 & 10.53 & 0.71 & 0.55 \\
\hline $\mathrm{F} \mathrm{K}_{2} \mathrm{O}$ & 8.00 & 6.26 & 2.58 & 0.84 \\
\hline
\end{tabular}


Int.J.Curr.Microbiol.App.Sci (2018) 7(1): 2420-2425

Table.5 Ready reckoner for vegetable cowpea (without FYM) for different targets

\begin{tabular}{|c|c|c|c|c|c|c|c|c|c|c|c|}
\hline \multicolumn{3}{|c|}{ Nutrients } & \multicolumn{3}{|c|}{ Yield target, $4 \mathrm{t} \mathrm{ha}^{-1}$} & \multicolumn{3}{|c|}{ Yield target, $5 \mathrm{t} \mathrm{ha}^{-1}$} & \multicolumn{3}{|c|}{ Yield target, $6 \mathrm{t} \mathrm{ha}^{-1}$} \\
\hline $\begin{array}{l}\mathrm{KMnO}_{4} \\
\mathrm{~N}\end{array}$ & $\begin{array}{l}\text { Bray`s } \\
\mathrm{P}\end{array}$ & $\begin{array}{l}\mathrm{NH}_{4} \mathrm{OAc} \\
-\mathrm{K}\end{array}$ & $\mathrm{N}$ & $\mathrm{P}_{2} \mathrm{O}_{5}$ & $\mathrm{~K}_{2} \mathrm{O}$ & $\mathrm{N}$ & $\mathrm{P}_{2} \mathrm{O}_{5}$ & $\mathrm{~K}_{2} \mathrm{O}$ & $\mathrm{N}$ & $\mathrm{P}_{2} \mathrm{O}_{5}$ & $\mathrm{~K}_{2} \mathrm{O}$ \\
\hline 100 & 5 & 100 & 213.07 & 217.51 & 998.96 & 288.84 & 290.33 & 1309.43 & 364.60 & 363.16 & 1619.90 \\
\hline 150 & 7 & 200 & 168.07 & 188.00 & 756.06 & 243.84 & 260.82 & 1066.52 & 319.60 & 333.65 & 1376.99 \\
\hline 200 & 9 & 300 & 123.07 & 158.49 & & 199 & 231 & 824 & 275 & 304 & 1134 \\
\hline 250 & 12 & 400 & 78.07 & 114.22 & 270.24 & 153.84 & 187.04 & 580.71 & 229.61 & 259.86 & 891.17 \\
\hline 300 & 14 & 500 & 33.07 & 84.70 & 27.33 & 108.84 & 157.53 & 337.80 & 184.61 & 230.35 & 648.27 \\
\hline 350 & 16 & 600 & 0.00 & 55.19 & 0.00 & 63.84 & 128.01 & 94.89 & 139.61 & 200.84 & 405.36 \\
\hline 400 & 18 & 700 & 0.00 & 25.68 & 0.00 & 18.84 & 98.50 & 0.00 & 94.61 & 171.33 & 162.45 \\
\hline
\end{tabular}

Table.6 Ready reckoner for vegetable cowpea (with FYM) for different targets

\begin{tabular}{|c|c|c|c|c|c|c|c|c|c|c|c|}
\hline & Nutrients & & & & & & & & & & \\
\hline \multirow[t]{2}{*}{$\begin{array}{l}\mathrm{KMnO}_{4} \\
\mathbf{N}\end{array}$} & \multirow[t]{2}{*}{ Bray`s P } & \multirow[t]{2}{*}{$\begin{array}{l}\mathrm{NH}_{4} \mathrm{OAc} \\
\mathrm{K}\end{array}$} & \multicolumn{2}{|c|}{$\begin{array}{l}\text { Yield target } \\
4 \mathrm{t} \mathrm{ha}^{-1}\end{array}$} & & \multicolumn{2}{|c|}{$\begin{array}{l}\text { Yield target } \\
5 \mathrm{t} \mathrm{ha}^{-1}\end{array}$} & & \multicolumn{2}{|c|}{$\begin{array}{l}\text { Yield target } \\
6 \text { tha }^{-1}\end{array}$} & \\
\hline & & & $\mathrm{N}$ & $\mathrm{P}_{2} \mathrm{O}_{5}$ & $\mathrm{~K}_{2} \mathrm{O}$ & $\mathrm{N}$ & $\mathrm{P}_{2} \mathrm{O}_{5}$ & $\mathrm{~K}_{2} \mathrm{O}$ & $\mathrm{N}$ & $\mathrm{P}_{2} \mathrm{O}_{5}$ & $\mathrm{~K}_{2} \mathrm{O}$ \\
\hline 100 & 5 & 100 & 78 & 0 & 932 & 154 & 12 & 1243 & 229 & 85 & 1553 \\
\hline 150 & 7 & 200 & 33 & 0 & 689 & 109 & 0 & 1000 & 184 & 55 & 1310 \\
\hline 200 & 9 & 300 & 0 & 0 & 446 & 64 & 0 & 757 & 139 & 26 & 1067 \\
\hline 250 & 12 & 400 & 0 & 0 & 204 & 19 & 0 & 514 & 94 & 0 & 824 \\
\hline 300 & 14 & 500 & 0 & 0 & 0 & 0 & 0 & 271 & 49 & 0 & 582 \\
\hline 350 & 16 & 600 & 0 & 0 & 0 & 0 & 0 & 28 & 4.34 & 0 & 339 \\
\hline 400 & 18 & 700 & 0 & 0 & 0 & 0 & 0 & 0 & 0 & 0 & 96 \\
\hline
\end{tabular}

Fertilizer Prescription Equations under IPNS for desired yield target

\begin{tabular}{|c|c|c|c|}
\hline Nutrients & & With FYM & Without FYM \\
\hline $\mathbf{N}$ & $=$ & $75.77 \mathrm{~T}-0.90 \mathrm{SN}-0.05 \mathrm{ON}$ & $75.77 \mathrm{~T}-0.90 \mathrm{SN}$ \\
\hline $\mathbf{P}_{2} \mathrm{O}_{5}$ & $=$ & $72.82 \mathrm{~T}-14.76 \mathrm{SP}-0.77 \mathrm{OP}$ & $72.82 \mathrm{~T}-14.76 \mathrm{SP}$ \\
\hline $\mathrm{K}_{2} \mathbf{O}$ & $=$ & $310.47 \mathrm{~T}-2.43 \mathrm{SK}-0.33 \mathrm{OK}$ & $310.47 \mathrm{~T}-2.43 \mathrm{SK}$ \\
\hline
\end{tabular}

Fertilizer prescription equations under IPNS for desired yield target

Soil test based fertilizer prescription equations for desired yield target of cowpea were formulated using the basic parameters and are furnished below:

Where, $\mathrm{FN}, \mathrm{FP}_{2} \mathrm{O}_{5}$ and $\mathrm{FK}_{2} \mathrm{O}$ are fertilizer $\mathrm{N}$, $\mathrm{P}_{2} \mathrm{O}_{5}$ and $\mathrm{K}_{2} \mathrm{O}$ in $\mathrm{kg} \mathrm{ha}^{-1}$, respectively; $\mathrm{T}$ is the yield target in $\mathrm{t} \mathrm{ha}{ }^{-1}$; $\mathrm{SN}, \mathrm{SP}$ and $\mathrm{SK}$, respectively are alkaline $\mathrm{KMnO}_{4}-\mathrm{N}$, Bray-P and $\mathrm{NH}_{4} \mathrm{OAc}-\mathrm{K}$ in $\mathrm{kg} \mathrm{ha}^{-1}$ in soil. ON, OP and $\mathrm{OK}$ are the quantities of $\mathrm{N}, \mathrm{P}$ and $\mathrm{K}$ supplied through FYM in $\mathrm{kg} \mathrm{ha}^{-1}$. Using the above equations, ready reckoners were formulated for a range of soil test values and desired yield targets $\left(4,5\right.$ and $\left.6 \mathrm{tha}^{-1}\right)$ of cowpea with chemical fertilizers alone as well as in combination with FYM (Tables 5 and 6).

For achieving yield target of $5 \mathrm{t} \mathrm{ha}^{-1}$ with soil test values of 200: 9: $300 \mathrm{~kg} \mathrm{ha}^{-1}$ of $\mathrm{KMnO}_{4}$ $\mathrm{N}$, Bray-P and $\mathrm{NH}_{4} \mathrm{OAc}-\mathrm{K}$, the fertilizer $\mathrm{N}$, $\mathrm{P}_{2} \mathrm{O}_{5}$ and $\mathrm{K}_{2} \mathrm{O}$ doses required were 199, 231 and $824 \mathrm{~kg} \mathrm{ha}^{-1}$, respectively. When FYM (1.15, 0.65 and 1.21 per cent of $\mathrm{N}, \mathrm{P}$ and $\mathrm{K}$, respectively) was applied @ $10 \mathrm{t} \mathrm{ha}^{-1}$ along 
with NPK, the required fertilizer $\mathrm{N}, \mathrm{P}_{2} \mathrm{O}_{5}$ and $\mathrm{K}_{2} \mathrm{O}$ doses were 64,0 and $757 \mathrm{~kg} \mathrm{ha}^{-1}$, respectively. Under IPNS system the required dose of fertilizer is low due to nutrient availability increased by FYM through mineralization. The results were in accordance with the findings of Singh et al., (2015). Santhi et al., (2010) reported that under integrated plant nutrient system, required dose of fertilizer to achieve desired yield target are reduced. These results clearly showed that the fertilizer requirements varied with the soil test values for the same level of crop production. Hence, balanced fertilization through soil testing becomes essential for increasing crop production. Similar results were found by Avtari et al., (2010) for 2 tha $^{-1}$ yield of yellow mustard.

Use of integrated plant nutrient system (IPNS) resulted in saving of fertilizer nutrients in vegetable cowpea. Target yield equations generated from STCR-IPNS technology ensures not only sustainable crop production but also economies use of costly fertilizer inputs.

\section{Acknowledgements}

The authors express sincere thanks to Indian Council of Agricultural Research, New Delhi and Kerala Agricultural University, Thrissur for funding and providing technical assistance to AICRP-STCR.

\section{References}

Avtari, S., Singh, S. and Kumar, S. 2010. Fertilizer prescription for target yield of yellow sarson Brassica rapa var. PYS 1 in Mollisols of Utarakhand. Pantnagar J. Res., 8: 2-6.

Bera, R., Seal, A., Bhattacharyya, P., Das, T. H., Sarkar, D. and Kangjoo, K. 2006. Targeted yield concept and a framework of fertilizer recommendation in irrigated rice domains of subtropical India. $J$. Zhejiang Univ., 7: 963-968.

Dwivedi, B.S., Singh, D., Tiwari, K.N., Swarup, A., Meena, M.C., Majumdar, K., Yadav, K.S. and Yadav, R.L. 2009. On-farm evaluation of SSNM in pearl millet based cropping systems on alluvial soils. Better crops- India pp. 25-27.

Piper, C. S. 1966. Soil and Plant Analysis. Hans Publications, Bombay.

Ramamoorthy, B., Narasimham, R. L. and Dinesh, R. S. 1967. Fertilizer application for specific yield targets on Sonora 64 (wheat). Indian Farming, 17: 43-45.

Santhi, R., Selvakumari, G. and Rani Perumal. 2010. Soil test based fertilizer recommendations under integrated plant nutrition system for rice-rice-pulse cropping sequence. J. Indian Soc. Soil Sci., 47: 288-294.

Sellamuthu, K. M., Santhi, R., Maragatham, S. and Dey, P. 2015. Balanced fertilizer prescription for glory lily through inductivecum- targeted yield model on an Alfisol. Res. Crops. 16 (3): 555-561.

Singh, V. V., Manoj Parihar., Singh, S. K., Sharma, P. K., Dey, P. 2015. Soil test based fertilizer prescriptions under integrated plant nutrient management system for maize in an Inceptisol of Varanasi. J. Indian Soc. Soil Sci. 63: 8387.

\section{How to cite this article:}

Beena, V.I., P. Dey and Raji Mol, R.P. 2018. Soil Test Based Fertilizer Recommendation under Integrated Plant Nutrition System for Vegetable Cowpea [Vigna unguiculata (L) Walp] in Ultisols of Kerala, India. Int.J.Curr.Microbiol.App.Sci. 7(01): 2420-2425.

doi: https://doi.org/10.20546/ijcmas.2018.701.291 